\title{
Improving Prosocial Behavior Through Virtual Media Based on Religious Values in Elementary School Students
}

\author{
Asroful Kadafi ${ }^{1,2}$, Bambang Budi Wiyono ${ }^{3}$, Muslihati ${ }^{4 *}$, M. Ramli ${ }^{5}$ \\ 1,4,5 Department of Guidance and Counseling, Universitas Negeri Malang, Malang, Indonesia, \\ 2 Department of Guidance and Counseling, Universitas PGRI Madiun, +628993598905, Madiun-Indonesia, \\ ${ }^{3}$ Department of Educational Administration, Universitas Negeri Malang, Malang Indonesia
}

\begin{abstract}
Prosocial behavior is important for every individual from an early age. This behavior can teach each individual to be able, share, cooperate, be generous, help and practice honesty. The level of students' prosocial behavior can also affect their academic achievement, so there needs to be an intervention to improve students' prosocial behavior since elementary school. To improve prosocial behavior in elementary school students, researchers provide treatment through virtual media based on religious values. This study uses a quasi-experimental design with a non-equivalent control group design model. Respondents in this study amounted to 24 respondents consisting of 2 groups, namely the control group 14 respondents, and the experimental group 14 respondents. Measuring the level of students' prosocial behavior using a prosocial behavior scale instrument consisting of 15 items. Data analysis was carried out using the Wilcoxon signed-rank test to determine differences in the prosocial behavior of respondents before and after the intervention and the Mann Whitnney test to see differences in the level of prosocial behavior of respondents between the experimental group and the control group. The results showed that virtual media based on religious values had a positive impact on improving the prosocial behavior of elementary school students. The implications of the results of this study can be used as a basis for decision-making to help students' problems, especially prosocial behavior.
\end{abstract}

Keywords: prosocial behavior, virtual media, religious values

\section{INTRODUCTION}

Achievement in the academic field must be the goal of every individual and parent while at school. One of these academic achievements can be influenced by the level of individual prosocial behavior (Ma, 2003; Zimmerman, 1989b). Individuals who have high prosocial behavior tend to be more accomplished than individuals with low prosocial behavior (Ma, 2003; Zimmerman, 1989b). Aljarrah \& Khataybeh (2021) prosocial behavior is also one of the skills that must be mastered in the 21st century. Prosocial behavior is a form of behavior that emphasizes the interests of others above personal interests (Baron \& Byrne, 2005). Prosocial behavior needs to be possessed by individuals from childhood as the basis for the development of children's abilities to interact with their environment more broadly outside the family environment (Sugandhi et al., 2020). Prosocial behavior that needs to be instilled in children is related to empathy, positive sympathies, such as altruistic behavior and helpful behavior (Batson, 2010; Eisenberg et al., 2016; Spinrad \& Eisenberg, 2009, 2015).

Efforts to improve prosocial behavior in elementary school students have often been carried out, including using play therapy (Agustin et al., 2015; Pratama, Hidayah, et al., 2019; Smith, 2014). The second intervention uses virtual media to shape positive behavior for elementary school students (Feng et al., 2020; Luo et al., 2020; Pradana et al., 2020). The next intervention uses a game strategy with collaboration, problem-solving, critical thinking/inquiry, global awareness, and the use of technology (Smith, 2014). In addition to these strategies, several studies have also been conducted studies on the development of prosocial behavior that is influenced by subjective well-being in elementary school-aged children (Chen et al., 2020; Liu et al., 2020; Su et al., 2019). The relationship between gratitude and student satisfaction has also been shown to influence the formation of students' prosocial behavior (Tian et al., 2016). Previous research studies indicate that a strategy is needed to develop prosocial behavior for elementary school students, which combines the design of development programs, motivation, modeling, games, paying attention to aspects of student welfare, integrating religious values, and utilizing technology (Feng et al., 2020; Kuswendi, 2019; Luo et al., 2020; Setiawati \& Ernawati, 2020).

Based on the results of the study above, strategies to increase prosocial behavior can be carried out with a comprehensive strategy by combining technological developments and

Corresponding Author e-mail: muslihati.fip@um.ac.id https://orcid.org/0000-0002-1565-773X

How to cite this article: Kadafi A, Wiyono BB, Muslihati, Ramli M, (2021). Improving ProsociOal Behavior Through Virtual Media Based on Religious Values in Elementary School Students. Pegem Journal of Education and Instruction, Vol. 11, No. 4, 2021, 230-236

Source of support: Nil

Conflict of interest: None.

DOI: $10.47750 /$ pegegog.11.04.22

Received: 17.08 .2021

Accepted: $10.09 .2021 \quad$ Publication: 01.10 .2021 
inculcating religious values simultaneously, and this is still rarely done by previous researchers. In this study, the treatment was carried out by using virtual media based on religious values as an effort to improve the prosocial behavior of elementary school students. The use of virtual media is provided by counselors through classical services by including religious values. Interventions with virtual media based on religious values can influence cognitive, affective and train students' skills such as in the form of behavior; helping, sharing, cooperating, generous and telling the truth since elementary school age. Based on these problems, this study wants to test whether the intervention with virtual media based on religious values is effective in increasing students' prosocial behavior?

\section{Method}

\section{Research Design}

This research was conducted at SD Negeri 1 Taji, Karas Magetan District, East Java, Indonesia. The design used in this study is a quasi-experimental design with a nonequivalent control group design model. Sampling was carried out purposively on the consideration of the level of prosocial behavior of the respondents, thus making the researchers choose a quasi-experimental design (Sugiyono, 2015; Wiyono, 2007). The effectiveness of the treatment can be seen by testing the difference in the results of the intervention between the experimental group and the control group (Sugiyono, 2015; Wiyono, 2007). The instrument used to measure the pre-test and post-test for both groups is the same, namely the prosocial behavior scale, this is an effort to anticipate the threat of internal validity (Creswell, 2013). Researchers also limit the characteristics of respondents, to anticipate the threat of external validity (Creswell, 2013).

\section{Intervention Procedure}

The intervention is given classically with stages including the initial or preliminary stage, this stage is carried out to ensure the readiness of participants to enter the next stage. The second stage is the core stage or activity, at this stage, the counselor facilitates the service, by delivering prosocial behavior material with virtual media based on religious values. The third stage, namely the closing and evaluation stages, at this stage is intended to ensure that the services provided provide benefits for participants (Kemendikbud, 2016; Prayitno, 2017). The intervention stages between the control group and the experimental group were the same, the difference was the media for delivering the material. The control group for service delivery was provided with simple PowerPoint media and the experimental group used virtual media based on religious values. The virtual media in this study is in the form of animated videos by integrating Islamic values according to the learning achievements of elementary school children. The material is presented in the form of a simple animation, paying attention to Islamic values that will be instilled so that students do not experience boredom when listening to the video being played. This media has also been tested by media experts and content experts, which stated that the media can be used to provide treatment to students.

The intervention in this study was carried out three times with a duration of 45 minutes per session. The intervention of the first meeting focused on the theme of helping and sharing according to Islam, the second meeting with the theme of sharing and generosity according to Islam, and the third meeting with the theme of honesty according to Islam. These three meeting schedules are expected to be able to facilitate the formation of prosocial behavior as a whole since elementary school age. Brief intervention by adopting the concept of Solution Focus Brief Counseling (SFBC) (Mulawarman et al., 2016). In addition to adopting the SFBC concept, researchers also pay attention to aspects of child welfare by maximizing the role of virtual media combined with simple games to provide meaningful learning for students (Feng et al., 2020; Luo et al., 2020; Mayfield et al., 2017; Streimann et al., 2020). Next, Islamic values were chosen because all respondents were Muslim and the results of previous research showed that the integration of Islamic values was effective in helping research respondents' problems (Faiz et al., 2019; Kadafi, 2016; Kadafi et al., 2021, 2019; Kadafi, Pratama, et al., 2020; Kadafi, Suharni, et al., 2020; Kadafi \& Ramli, 2017).

\section{Participants}

In this research, the respondents were 28 elementary school students which were divided into two, namely, 14 respondents as the experimental group and 14 respondents as the control group. The determination of respondents based on the level of prosocial behavior is still low. The sample was taken by purposive sampling technique, this technique was chosen to obtain a sample according to the needs of the researcher or according to predetermined criteria, namely the category of low prosocial behavior (Sugiyono, 2015). The characteristics of the respondents include difficulty to share, unwilling to help, unwilling to donate, difficulty to cooperate, and miserly (Eisenberg et al., 2015; Hudaniah \& Dayakisni, 2009; Pratama, Kadafi, et al., 2019). The detailed condition of the respondents' prosocial behavior is presented in table 1 , the table shows that the two groups of respondents' prosocial behavior are in the moderate category. The category of respondent's prosocial behavior is used as the basis for determining the research sampled purposively. Measurement of prosocial behavior is done with a prosocial behavior scale instrument.

\section{Instrument}

Respondents' prosocial behavior data was measured using a prosocial behavior scale developed from the prosocial instrument Pastorelli et al (1997) and referring to indicators 
of prosocial behavior from Eisenberg et al (2015); Hudaniah \& Dayakisni, (2009); Pratama et al (2019), namely: sharing, helping, donating, collaborating, and generous behavior. The prosocial behavior scale consists of 15 items and uses a scale of 4 . This prosocial behavior scale has passed validity and reliability tests. The results of the validity test of the prosocial behavior scale to 64 respondents showed the lowest value was 0.394 and the highest value was 0.926 and the r-table in the $5 \%$ significance level was 0.254 . The results of the validity test of the prosocial behavior scale show that of the 15 items, all of them are declared valid because the results of the calculation show that the r-count is greater than the r-table. The results of the reliability test show a value of 0.869 or greater than the r-table of 0.254 , which means that the instrument is declared reliable.

\section{Data Analysis}

The first data analysis used descriptive statistics to determine the percentage difference between the results before and after the test was carried out, and to determine the percentage difference between the control group and the experimental group. Testing the effectiveness of the intervention, the researcher used the Wilcoxon signed-rank test analysis to determine the differences in the prosocial behavior of respondents before the intervention and after the intervention in both the control and experimental groups and the Mann Whitnney test to see differences in the level of prosocial behavior of respondents between the experimental group and the control group. The two analytical tests were determined by the researcher based on the non-fulfillment of the research assumptions and the provisions in parametric statistics. So the researchers set a non-parametric test to find out the effectiveness of virtual media based on religious values to improve the prosocial behavior of elementary school students.

\section{Results \\ Descriptive data analysis}

The results of the research on the demographics of the participants obtained information, including age, gender, and level of prosocial behavior before being given treatment, both for the experimental group and the control group. Detailed information is presented in Table 1.

Table 1 shows the demographic information of the research respondents. In this study, researchers used 2 research groups, namely the experimental group and the control group. Each of these two groups consisted of 14 respondents. The age of respondents in the 9-year experimental group were 5 respondents, 5 respondents for 10 years, and 4 respondents for 11 years. The age of respondents in the control group is known: 9 years 4 respondents, 10 years 6 respondents, and 11 years 4 respondents. In the experimental group, there were 6 male respondents and 8 female respondents. For the control group, there were 7 male respondents and 7 female respondents. The results showed that there was a higher tendency for prosocial behavior at the age of 10 years or the fourth grade of elementary school. Girls are more likely to have higher prosocial behavior scores than boys. One of the reasons for this finding is that girls are afraid of other people's negative judgments and adhere to norms more (Watanabe \& Lee, 2016).

The latest information from table 1 is related to the level of prosocial behavior of respondents, in the experimental group the average level of prosocial behavior is 36.14 and the level of prosocial behavior in the control group is 36.86 . The average level of prosocial behavior shows the level of prosocial behavior of respondents in both groups is in the medium category. Furthermore, data analysis to determine differences in prosocial behavior and the level of prosocial

Table. 1. Demographic Info of Experimental Group Participants and Control Group

\begin{tabular}{|c|c|c|c|c|c|c|}
\hline \multirow[b]{2}{*}{$\begin{array}{l}\text { Respondent } \\
\text { Number }\end{array}$} & \multicolumn{3}{|c|}{ Experimental Group } & \multicolumn{3}{|c|}{ Control Group } \\
\hline & Age & Gender & $\begin{array}{l}\text { Level of Prosocial } \\
\text { Behavior }\end{array}$ & Age & Gender & $\begin{array}{l}\text { Level of Prosocial } \\
\text { Behavior }\end{array}$ \\
\hline 1 & 9 & Male & 38 & 10 & Male & 37 \\
\hline 2 & 9 & Female & 38 & 9 & Male & 36 \\
\hline 3 & 11 & Male & 39 & 10 & Female & 37 \\
\hline 4 & 11 & Female & 40 & 11 & Female & 38 \\
\hline 5 & 11 & Male & 39 & 11 & Male & 37 \\
\hline 6 & 10 & Female & 39 & 11 & Male & 38 \\
\hline 7 & 9 & Female & 38 & 9 & Male & 36 \\
\hline 8 & 10 & Female & 38 & 10 & Female & 37 \\
\hline 9 & 10 & Female & 38 & 10 & Female & 37 \\
\hline 10 & 9 & Male & 36 & 9 & Male & 28 \\
\hline 11 & 11 & Male & 39 & 10 & Female & 36 \\
\hline 12 & 9 & Female & 37 & 10 & Female & 36 \\
\hline 13 & 10 & Male & 38 & 11 & Male & 37 \\
\hline 14 & 10 & Female & 38 & 9 & Female & 36 \\
\hline
\end{tabular}


behavior of respondents before and after being given treatment (experimental group) is descriptively presented in table 2 .

Table 2 shows that $\mathrm{N}$ or respondents in each group amounted to 14 respondents. The mean or average value of prosocial behavior before treatment was 38.21 and the average value after treatment that occurred in the experimental group was 50.71. The standard deviation before treatment was 0.975 and after treatment was 0.726 . Looking at the results of this descriptive analysis, it is known that there are differences in respondents' prosocial behavior between before and after treatment, or an increase in the average score of 11.79. The results in the experimental group showed that giving treatment through virtual media based on religious values was able to increase individual prosocial behavior.

\section{The effectiveness of virtual media based on religious values in increasing prosocial behavior}

The results of the hypothesis analysis of the effectiveness of religious value-based virtual media seen from the values before and after treatment with the Wilcoxon signed-rank test, as well as the results of the different tests between the experimental group and the control group with the Mann Whitney test are presented in Table 3.

Table 3 shows the z-score of respondents' prosocial behavior in the control group of -2.714 and a significance value of 0.007 . These results indicate that the significance value of prosocial behavior is 0.007 , which is greater than the critical research limit of 0.05 , which means that there is no difference in the level of respondents' prosocial behavior. between before and after treatment in the control group. The Z-score of respondents' prosocial behavior in the experimental group was -3.325 and the significance value was 0.001 . These results indicate that

Table. 2. Descriptive Analysis of Pre-Test and Post-Test Prosocial Behavior of the Experimental Group and the Control Group

\begin{tabular}{lllll}
\hline & \multicolumn{2}{c}{ Experimental Group } & \multicolumn{2}{c}{ Control Group } \\
\cline { 2 - 5 } Description & Pre-test & Post-test & Pre-test & Post-test \\
\hline $\mathrm{N}$ & 14 & 14 & 14 & 14 \\
Mean & 38,21 & 50,71 & 36,143 & 36,86 \\
Std. Deviation & 0,975 & 0,726 & 2,445 & 1,834 \\
Minimum & 36 & 50 & 28 & 31 \\
Maximum & 40 & 52 & 38 & 38 \\
\hline
\end{tabular}

Table 3. Results of Prosocial Behavior Analysis through the Wilcoxon Signed Rank Test and the Mann Whitnney Test

\begin{tabular}{lll}
\hline Test & $z$-score & $p$ \\
\hline Wilcoxon Signed-Rank & & \\
Control Group & $-2,714$ & 0,07 \\
Experimental Group & $-3,325$ & 0,001 \\
Mann Whitnney & $-4,583$ & 0,000 \\
\hline
\end{tabular}

the significance value of prosocial behavior is 0.001 which is smaller than the critical research limit of 0.05 , which means that there are differences in the level of prosocial behavior of respondents between before and after receiving treatment in the experimental group. The Mann Whitnney test shows that the respondents' $\mathrm{z}$-score of prosocial behavior is -4.583 and the significance value is 0.000 . These results indicate that the significance value of prosocial behavior of 0.000 is smaller than the critical research limit of 0.05 , which means that there are differences in respondents' prosocial behavior between the experimental group treated with religious value-based virtual media and the control group treated with conventional media. Based on these results, it shows that the treatment of respondents through the provision of interventions with virtual media based on religious values is effective in increasing the prosocial behavior of elementary school students $(Z=$ $-4.583 ; \mathrm{p}<0.000)$.

\section{Discussion}

The intervention in this study was conducted in three meetings. At the first meeting, the service was provided with the theme of helping and cooperating according to Islam. The value instilled at the first meeting is following the QS. Al Maidah verse 2, this verse calls for every Muslim to cooperate in goodness and QS. Al Hujurat verse 10, in this verse, shows that all believers are brothers, for that it is an obligation for every Muslim to cooperate with each other in goodness (Al-Quran, 2015). The second meeting instills the value of variety and generosity, which refers to the QS. Ali Imron verse 92 which teaches to give what we love and reminds us that our every behavior is known to Allah SWT, the second verse refers to the QS. Al Baqarah 267 which reflects the behavior of generosity, namely, giving the best of what we have to charity (Al-Quran, 2015). The third meeting instills the value of honesty according to QS Al Ahzab verses 70-71 which teaches every Muslim to speak the truth, be honest, straight and not deviate (Al-Quran, 2015). The internalization of prosocial values according to Islam is packaged in an animated video as a form of virtual media that can affect individual cognitive and have an impact on changing the behavior of elementary school students to become more prosocial. At each meeting, the researcher emphasizes each individual being able to evaluate and demonstrate new prosocial behavior based on the material that has been presented, as a form of higher-order thinking (Singh, 2018).

A simple and short intervention that is three times adopting the concept of a Solution Focus Brief Counseling (SFBC) approach (Mulawarman et al., 2016). In this study, researchers focus on the goals that have been set and design interventions with virtual media carefully. Media development is based on input from media and content experts. This short intervention is also to pay attention to aspects of student welfare, through virtual media combined with simple games 
can provide meaningful learning for students (Feng et al., 2020; Luo et al., 2020; Mayfield et al., 2017; Streimann et al., 2020). Environmental conditions also affect the success of the student learning process more than the length or duration of the learning process (Bandura, 2012). The process of inculcating values that can influence individual behavior can be started from the immediate environment and at an early age (Apriani et al., 2018). One of the behaviors that need to be possessed by each individual is prosocial behavior as a provision for them to live in society and also to achieve success in learning (Zimmerman, 1989a).

The determination of elementary school students is not only based on the importance of inculcating character from an early age, but it is also because elementary school students are faced with living conditions at home and in the community that can contribute to stress and can have an impact on learning, behavior, and overall academic performance (Harpin et al., 2016). Rapid technological developments also trigger the emergence of maladaptive behaviors such as cyberbullying behavior (Aizenkot \& Kashy-Rosenbaum, 2019). Adaptive mal behavior that appears can be reduced by strengthening prosocial behavior (Barón et al., 2018). Prosocial behavior can prevent bullying or other aggressive behavior among elementary school students (Grossman et al., 1997; McCarty et al., 2016). Strengthening and character building, especially prosocial behavior, should ideally be carried out since elementary school age (Chandler, 2006; Muslihati, 2019). Prosocial behavior appears when cognitive abilities show development, which can change expression over time, such as sharing behavior which is one of the important aspects of prosocial behavior (Flook et al., 2019). Cognitive empathy which consists of two factors, namely: sensitivity to the emotions (feelings) of others and perspectivetaking, also has a positive relationship with prosocial behavior (Murakami et al., 2014).

Improved prosocial behavior and children's well-being can be achieved by utilizing virtual media combined with games (Feng et al., 2020; Luo et al., 2020; Mayfield et al., 2017; Streimann et al., 2020). The use of virtual media must also be accompanied by learning that facilitates collaboration, problem solving, critical thinking/inquiry, awareness, and the use of technology (Pletz, 2021; Smith, 2014). Environmentbased virtual technology is a tool for teaching elementary school children social skills (Baker et al., 2009). Virtual learning can also help to reduce bullying behavior (M. et al., 2010). The use of technology will have a positive impact if it gets effective support from the school environment (Baisey, 2020). A conducive learning environment can develop students' prosocial behavior. Prosocial behavior consists of a set of behaviors that benefit others in the form of sharing and helping. A conducive and interactive learning environment plays an important role in creating the ability for students to develop prosocial behavior (Shin et al., 2019; Villardón-
Gallego et al., 2018). Effective classroom management from teachers has also been shown to be able to reduce aggressive behavior (Chuang et al., 2020). In addition to paying attention to environmental factors in the use of virtual media, it is also necessary to pay attention to aspects of students' psychological and social-emotional welfare (Bradshaw et al., 2012; Chen et al., 2020) as well as students' religious aspects in building students' prosocial (Kadafi, Suharni, et al., 2020). The results of this study indicate that student behavior can be influenced by the way students think and behave in responding to the existing stimulus (Bandura, 2012). Positive stimuli (internalization of religious values) through virtual media by paying attention to all aspects that affect individual development are very effective in influencing the formation of positive behaviors such as prosocial behavior

\section{Conclusion and Suggestion}

This study concludes that the use of virtual media based on religious values can affect the increase in prosocial behavior of elementary school students. The use of virtual media can make it easier for elementary school students to understand the material presented, besides that virtual media can influence students' emotions which provide an actual picture of what students should do. This finding also shows that the services provided by conventional media are not effective in influencing the prosocial behavior of elementary school students. Other findings show that prosocial behavior is an important thing that every student needs to have from elementary school age, to support their academic success.

This study still has limitations, including: research respondents are still limited and homogeneous in nature, so caution is needed in making generalizations. From the existing limitations, the researcher suggests conducting further research with more and heterogeneous respondents

\section{References}

Agustin, A. K. M., Padmomartono, S., \& Windrawanto, Y. (2015). Meningkatkan Perilaku Prososial Anak Usia 10-12 Tahun melalui Terapi Bermain di PPA Agape IO-847 Salatiga. Jurnal Psikologi, 17(2), 16-22. https://repository.uksw.edu/ handle/123456789/6418

Aizenkot, D., \& Kashy-Rosenbaum, G. (2019). Cyberbullying Victimization in WhatsApp Classmate Groups among Israeli Elementary, Middle, and High School Students. Journal of Interpersonal Violence. https://doi. org $/ 10.1177 / 0886260519842860$

Al-Quran. (2015). Departemen Agama RI. CV Darus Sunnah.

Aljarrah, K., \& Khataybeh, A. (2021). Representing teaching staff in Jordanian universities for the 21st century skills. Pegem Journal of Education and Instruction, 11(3), 17-25. https://www.pegegog. net/index.php/pegegog/article/view/1315

Apriani, K., Budjang, G., \& Imran. (2018). Peran Orang Tua dalam Pendidikan Anak. Media.Nationalgeographic.Co.Id. 
Improving Prosocial Behavior Through Virtual Media Based on Religious Values in Elementary School Students

Baisey, M. (2020). The impact of participation in an elementary behavior support program on students' prosocial behavior, school functioning and academic performance. Dissertation Abstracts International Section A: Humanities and Social Sciences.

Baker, J., Parks-Savage, A., \& Rehfuss, M. (2009). Teaching social skills in a virtual environment: An exploratory study. Journal for Specialists in Group Work. https://doi. org/10.1080/01933920903039195

Bandura, A. (2012). Social cognitive theory. In Handbook of Theories of Social Psychology: Volume 1. https://doi. org/10.4135/9781446249215.n18

Barón, M. J. O., Bilbao, I. E., Urquijo, P. A., López, S. C., \& Jimeno, A. P. (2018). Moral emotions associated with prosocial and antisocial behavior in school-aged children. Psicothema. https://doi.org/10.7334/psicothema2016.143

Baron, R. A., \& Byrne, D. (2005). Psikologi Sosial (Jilid 2 Ed). Erlangga.

Batson, C. D. (2010). The Empathy-Altruism Hypothesis. In Altruism in Humans (pp. 11-32). https://doi.org/10.1093/acpr of:oso/9780195341065.003.0002

Bradshaw, C. P., Waasdorp, T. E., \& Leaf, P. J. (2012). Effects of school-wide positive behavioral interventions and supports on child behavior problems. Pediatrics. https://doi.org/10.1542/ peds.2012-0243

Chandler, M. K. (2006). The effects of a character education program on elementary students' prosocial competence. Dissertation Abstracts International Section A: Humanities and Social Sciences.

Chen, X., Tian, L., \& Huebner, E. S. (2020). Bidirectional Relations Between Subjective Well-Being in School and Prosocial Behavior Among Elementary School-Aged Children: A Longitudinal Study. Child and Youth Care Forum. https://doi. org/10.1007/s10566-019-09518-4

Chuang, C. C., Reinke, W. M., \& Herman, K. C. (2020). Effects of a Universal Classroom Management Teacher Training Program on Elementary Children With Aggressive Behaviors. School Psychology. https://doi.org/10.1037/spq0000351

Creswell, J. (2013). Qualitative, quantitative, and mixed methods approaches. In Research design.

Eisenberg, N., Fabes, R. A., Karbon, M., Murphy, B. C., Wosinski, M., Polazzi, L., Carlo, G., \& Juhnke, C. (2016). The Relations of Children's Dispositional Prosocial Behavior to Emotionality, Regulation, and Social Functioning, and Social Functioning. Child Development. https://doi.org/10.2307/1131874

Eisenberg, N., Spinrad, T. L., \& Knafo-Noam, A. (2015). Prosocial Development. In Handbook of Child Psychology and Developmental Science. https://doi.org/10.1002/9781118963418. childpsy315

Faiz, A., Yandri, H., Kadafi, A., Mulyani, R. R., Nofrita, N., \& Juliawati, D. (2019). Pendekatan Tazkiyatun An-Nafs untuk membantu mengurangi emosi negatif klien. Counsellia: Jurnal Bimbingan Dan Konseling, 9(1), 65-78. https://doi.org/http:// doi.org/10.25273/counsellia.v9i1.4300

Feng, Q., Li, G., Yang, T., \& Luo, H. (2020). Exploring the Potential of Virtual Reality for Child Pedestrian Safety Training: A Case Study in China. Proceedings - 2020 International Symposium on Educational Technology, ISET 2020. https://doi.org/10.1109/ ISET49818.2020.00027
Flook, L., Zahn-Waxler, C., \& Davidson, R. J. (2019). Developmental differences in prosocial behavior between preschool and late elementary school. Frontiers in Psychology. https://doi. org/10.3389/fpsyg.2019.00876

Grossman, D. C., Neckerman, H. J., Koepsell, T. D., Liu, P. Y., Asher, K. N., Beland, K., Frey, K., \& Rivara, F. P. (1997). Effectiveness of a violence prevention curriculum among children in elementary school: A randomized controlled trial. Journal of the American Medical Association. https://doi.org/10.1001/ jama.277.20.1605

Harpin, S., Rossi, A., Kim, A., \& Swanson, L. (2016). Behavioral Impacts of a Mindfulness Pilot Intervention for Elementary School Students. Education.

Hudaniah, \& Dayakisni, T. (2009). Psikologi Sosial. UMM Press.

Kadafi, A. (2016). Efektivitas Bimbingan Kelompok Islami untuk Meningkatkan Aspirasi Karir Mahasiswa. Universitas Ahmad Dahlan, 5(1), 43-48. https://doi.org/http://dx.doi.org/10.12928/ psikopedagogia.v5i1.4482

Kadafi, A., Alfaiz, A., Ramli, M., Asri, D. N., \& Finayanti, J. (2021). The Impact of Islamic Counseling Intervention towards Students' Mindfulness and Anxiety during the COVID-19 Pandemic. Islamic Guidance and Counseling Journal, 4(1), 55-66. https:// doi.org/https://doi.org/10.25217/igcj.v4i1.1018

Kadafi, A., Pratama, B. D., Suharni, S., \& Mahmudi, I. (2020). Mereduksi Perilaku Phubbing melalui Konseling Kelompok Realita Berbasis Islami. JBKI (Jurnal Bimbingan Konseling Indonesia), 5(2), 31-34. https://journal.stkipsingkawang.ac.id/ index.php/JBKI/article/view/1721

Kadafi, A., Ramatus, M. R., \& Desy, R. N. K. (2019). INTERNALISASI NILAI RELIGIUS DALAM MEREDUKSI PERILAKU PROKRASTINASI AKADEMIK. Prosiding Seminar Nasional Hasil Penelitian LPPM Universitas PGRI Madiun, 140-144. http://prosiding.unipma.ac.id/index.php/SNHP/article/ view/779

Kadafi, A., \& Ramli, M. (2017). Integrated qs al mudatsir in the reality group conseling to grow the character of students academic responsibility. Counsellia: Jurnal Bimbingan Dan Konseling, 7(2), 117-125. https://doi.org/http://doi. org/10.25273/counsellia.v7i2.1867

Kadafi, A., Suharni, S., Mahmudi, I., \& Pratama, B. D. (2020). Urgency Strengthening Religious Values in Guidance and Counseling Programs in the New Normal Era. Proceedings of the 1 St International Conference on Information Technology and Education (ICITE 2020), 285-290. https://doi.org/https:// doi.org/10.2991/assehr.k.201214.250

Pedoman Bimbingan dan Konseling pada Pendidikan Dasar dan Pendidikan Menengah, (2016) (testimony of Kemendikbud).

Kuswendi, U. (2019). TEACHER STRATEGY IN DEVELOPMENT PROSOCIAL BEHAVIOR OF STUDENTS IN ELEMENTARY SCHOOL. PrimaryEdu - Journal of Primary Education. https:// doi.org/10.22460/pej.v3i1.1231

Liu, W., Su, T., Tian, L., \& Huebner, E. S. (2020). Prosocial Behavior and Subjective Well-Being in School among Elementary School Students: the Mediating Roles of the Satisfaction of Relatedness Needs at School and Self-Esteem. Applied Research in Quality of Life. https://doi.org/10.1007/s11482-020-09826-1

Luo, H., Yang, T., Kwon, S., Zuo, M., Li, W., \& Choi, I. (2020). Using virtual reality to identify and modify risky pedestrian 
behaviors amongst Chinese children. Traffic Injury Prevention. https://doi.org/10.1080/15389588.2019.1694667

M., S., D., W., N., V., S., W., S., W., W., S., S., E., L., H., A., P., E., A., K., D., \& R., A. (2010). Virtual learning intervention to reduce bullying victimization in primary school: A controlled trial. In Journal of Child Psychology and Psychiatry and Allied Disciplines.

Ma, H. K. (2003). The relation of academic achievement, family and classroom social environment, and peer interactions to prosocial and antisocial behavior of chinese children. Psychologia. https://doi.org/10.2117/psysoc.2003.163

Mayfield, C. A., Child, S., Weaver, R. G., Zarrett, N., Beets, M. W., \& Moore, J. B. (2017). Effectiveness of a Playground Intervention for Antisocial, Prosocial, and Physical Activity Behaviors. Journal of School Health. https://doi.org/10.1111/josh.12506

McCarty, S., Teie, S., McCutchen, J., \& Geller, E. S. (2016). Actively caring to prevent bullying in an elementary school: Prompting and rewarding prosocial behavior. Journal of Prevention and Intervention in the Community. https://doi.org/10.1080/10852 352.2016.1166809

Mulawarman, M., Munawaroh, E., \& Nugraheni, E. P. (2016). Effectiveness of solution focus brief counseling approach (SFBC) in developing student career adaptability. COUNSEDU| The International Journal of Counseling and Education. https://doi.org/10.23916/10-15.0016.11-i33b

Murakami, T., Nishimura, T., \& Sakurai, S. (2014). Relation between Cognitive/Emotional Empathy and Prosocial and Aggressive Behaviors in Elementary and Middle School Students. The Japanese Journal of Developmental Psychology, 25(4), 399-411. https://doi.org/10.11201/jjdp.25.399

Muslihati, M. (2019). Peran Bimbingan dan Konseling dalam Penguatan Pendidikan Karakter di Sekolah Menengah Kejuruan. Jurnal Kajian Bimbingan Dan Konseling, 4(3), 101-108. https://doi.org/10.17977/um001v4i32019p101

Pastorelli, C., Barbaranelli, C., Cermak, I., Rozsa, S., \& Caprara, G. V. (1997). Measuring emotional instability, prosocial behavior and aggression in pre-adolescents: A cross-national study. Personality and Individual Differences. https://doi.org/10.1016/ S0191-8869(97)00056-1

Pletz, C. (2021). Which Factors Promote and Inhibit the Technology Acceptance of Immersive Virtual Reality Technology in Teaching-Learning Contexts? Results of an Expert Survey. International Journal of Emerging Technologies in Learning, 16(13), 248-272. https://doi.org/https://doi.org/10.3991/ijet. v16i13.20521

Pradana, L. N., Sholikhah, O. H., Maharani, S., \& Kholid, M. N. (2020). Virtual mathematics kits (VMK): Connecting digital media to mathematical literacy. International Journal of Emerging Technologies in Learning. https://doi.org/10.3991/ ijet.v15i03.11674

Pratama, B. D., Hidayah, R. N., \& Hargiyansari, T. (2019). Peran Pendidik dalam Menumbuhkan Perilaku Prososial Anak dengan Media Permainan Tradisional. Prosiding Seminar Nasional Hasil Penelitian LPPM Universitas PGRI Madiun, 20-23. http:// prosiding.unipma.ac.id/index.php/SNHP/article/view/761

Pratama, B. D., Kadafi, A., \& Suharni. (2019). Meningkatkan Perilaku Prososial Mahasiswa melalui Konseling Kelompok Realita. Universitas PGRI Madiun.

Prayitno. (2017). Konseling Profesional yang Berhasil: Layanan dan Kegiatan Pendukung. Rajawali Pers.
Setiawati, E., \& Ernawati, I. (2020). The Evaluation of Students' Prosocial Behavior On Primary Education Level. Al-Bidayah: Jurnal Pendidikan Dasar Islam. https://doi.org/10.14421/ al-bidayah.v11i2.205

Shin, H., Ryan, A. M., \& North, E. (2019). Friendship processes around prosocial and aggressive behaviors: The role of teacherstudent relatedness and differences between elementary-school and middle-school classrooms. Merrill-Palmer Quarterly. https://doi.org/10.13110/merrpalmquar1982.65.2.0232

Singh, M. G. (2018). Critical thinking skills and its development strategies. International Journal of Trend in Scientific Research and Development. https://doi.org/10.31142/ijtsrd11091

Smith, T. K. (2014). Elementary science instruction: Examining a virtual environment for evidence of learning, engagement, and 21st century competencies. Education Sciences. https:// doi.org/10.3390/educsci4010122

Spinrad, T. L., \& Eisenberg, N. (2009). Chapter: Empathy, prosocial behavior, and positive development in schools. [References]. In Gilman, Rich [Ed]; Huebner, E.

Spinrad, T. L., \& Eisenberg, N. (2015). Empathy, Prosocial Behavior, and Positive Development in Schools. In Handbook of Positive Psychology in Schools. https://doi.org/10.4324/9780203106525.ch6

Streimann, K., Selart, A., \& Trummal, A. (2020). Effectiveness of a Universal, Classroom-Based Preventive Intervention (PAX GBG) in Estonia: a Cluster-Randomized Controlled Trial. Prevention Science. https://doi.org/10.1007/s11121-019-01050-0

Su, T., Tian, L., \& Huebner, E. S. (2019). The reciprocal relations among prosocial behavior, satisfaction of relatedness needs at school, and subjective well-being in school: A three-wave cross-lagged study among Chinese elementary school students. Current Psychology. https://doi.org/10.1007/s12144-01900323-9

Sugandhi, N. M., Saomah, A., Zahirah, A. H., Solehuddin, M., \& Suryana, D. (2020). The profile of prosocial behavior in elementary school children. International Journal of Scientific and Technology Research.

Sugiyono. (2015). Metode Penelitian Kualitatif Kuantitatif dan RむD. Alfabeta.

Tian, L., Chu, S., \& Huebner, E. S. (2016). The Chain of Relationships Among Gratitude, Prosocial Behavior and Elementary School Students' School Satisfaction: The Role of School Affect. Child Indicators Research. https://doi.org/10.1007/s12187-015-9318-2

Villardón-Gallego, L., García-Carrión, R., Yáñez-Marquina, L., \& Estévez, A. (2018). Impact of the interactive learning environments in children's prosocial behavior. Sustainability (Switzerland). https://doi.org/10.3390/su10072138

Watanabe, Y., \& Lee, K. (2016). Children's motives for admitting to prosocial behavior. Frontiers in Psychology. https://doi. org/10.3389/fpsyg.2016.00220

Wiyono, B. B. (2007). Metodologi Penelitian: Pendekatan Kuantitatif, Kualitatif, dan Action Research (Burhanuddin (ed.)). Fakultas Ilmu Pendidikan Universitas Negeri Malang.

Zimmerman, B. J. (1989a). A social cognitive view of self-regulated academic learning. Journal of Educational Psychology. https:// doi.org/10.1037//0022-0663.81.3.329

Zimmerman, B. J. (1989b). A Social Cognitive View of Self-Regulated Academic Learning. Journal of Educational Psychology. https:// doi.org/10.1037/0022-0663.81.3.329 